\title{
Two Cases of Extragenital Infection by Mycoplasma hominis
}

\author{
Mi Ae Jang, Min Jung Song, Jang Ho Lee, Nam Yong Lee \\ Department of Laboratory Medicine and Genetics, Samsung Medical Center, \\ Sungkyunkwan University School of Medicine, Seoul, Korea
}

Mycoplasma hominis is a commensal organism in the genitourinary tract. Extragenital infections by $M$. hominis are rare, and its occurrence is usually limited to immunocompromised patients. Here we report two patients with extragenital infection by $M$. hominis. The first patient, a woman with angioimmunoblastic T cell lymphoma, underwent autologous peripheral blood stem cell transplantation. The second patient, a woman with endometrial cancer, received laparoscopically-assisted vaginal hysterectomy. They both presented with septic symptoms, including fever, and M. hominis was isolated from pleural effusion and ascitic fluid, respectively. We are reporting these two cases of extragenital infection by $M$. hominis with a literature review to emphasize that the rapid isolation of $M$. hominis with early treatment can lead to a better prognosis. (Korean J Clin Microbiol 2010;13:47-50)

Key Words: Mycoplasma hominis, Pleural effusion, Ascitic fluid

\section{서 론}

Mycoplasma hominis는 비뇨생식기 계에 존재하는 공생균으 로 집락 형성률은 20 50\%에 이른다[1,2]. M. hominis가 병원 성을 나타내는 경우는 드물지만 신우신염, 골반감염, 산후열 등 의 국소적인 감염이나 출산 시 균집락이 있는 산도를 통과하면 서 신생아에서 뇌수막염, 심내막염 등의 감염을 일으키는 것으 로 알려져 있다[2-4]. 또한 숙주의 여러 가지 요인, 예를 들어 면역저하, 암, 외상, 비뇨기계 시술과 관련된 합병증 또는 수술 등과 관련하여 균혈증, 창상감염, 화농성 관절염, 심내막염, 폐 렴 등의 비뇨생식기 외 감염을 일으킬 수 있다[3-7]. 이식환자 와 면역저하 환자의 체액에서 M. hominis가 분리되었던 보고는 있었으나[3,8], 국내에서 환자의 흉수나 복수에서 M. hominis가 분리되었던 증례는 찾지 못하였다.

일반적으로 M. hominis의 감염은 경미한 증상을 보이지만 면 역저하 환자에서는 심각한 질환을 일으킬 수 있으며[7,9] 특히 장기이식 환자에서는 이식 실패를 초래하거나 사망에까지 이 르게 할 수 있다[9]. 따라서 신속한 균주의 동정과 적절한 조기 치료가 환자의 치료경과 향상에 상당한 도움을 줄 수 있다. 저 자들은 최근에 면역저하 환자를 포함한 2 명의 환자의 흉수와

Received 24 August, 2009, Revised 11 December, 2009 Accepted 20 December, 2009

Correspondence: Nam Yong Lee, Department of Laboratory Medicine and Genetics, Samsung Medical Center, Sungkyunkwan University School of Medicine, 50, Irwon-dong, Gangnam-gu, Seoul 135-710, Korea. (Tel) 82-2-3410-2706, (Fax) 82-2-3410-2719, (E-mail) micro.lee@samsung.com
복수에서 M. hominis를 분리하였기에 문헌고찰과 함께 보고하 는 바이다.

증 례

\section{1. 증례 1}

혈관면역모세포 $\mathrm{T}$ 세포 림프종(angioimmunoblastic $\mathrm{T}$ cell lymphoma)으로 항암치료를 받은 57세 여자 환자가 자가 말초 혈액 조혈모세포 이식(autologous peripheral blood stem cell transplantation) 후 발열 및 출혈성 방광염이 발생하여 혈액 및 요 배양 검사가 의뢰되었다. 요 배양 검사에서는 균주가 분리 되지 않았으나 혈액 배양 검사에서 Escherichia coli가 분리되 어 감수성 있는 cefepime으로 치료하던 중 이식 후 3 개월째 발 열과 함께 좌측 흉수가 증가하였다. 당시 흉수 검체는 적혈구 수 $>1,000 / \mu \mathrm{L}$, 백혈구 수 $60 / \mu \mathrm{L}$ (호중구 $14 \%$, 림프구 $15 \%$, 기타 $71 \%), \mathrm{pH} 7.0$, 단백질 $3,776.1 \mathrm{mg} / \mathrm{dL}$, 당 $156 \mathrm{mg} / \mathrm{dL}$ 으로 삼출액 소견을 보였으나, 원인균은 분리되지 않았다. 이후 경험 적 항생제 치료를 하였으나 환자상태는 지속적으로 악화되었 고, 여러 번의 흉강천자에도 불구하고, 원인균은 분리되지 않았 다. 4번째 흉강천자 후 얻은 흉수 검체에서 호기성 배양 결과는 음성이었으나 혐기성 배양 4 일째 브루셀라 혈액한천배지에서 작고 반투명한 집락이 관찰되었다(Fig. 1). 하지만 그람 염색상 에서 균이 관찰되지 않아 M. hominis 감염 의심 하에 mycoplasma 특수배지인 pleuropneumonia-like organism agar (PPLO) 에 계대 배양을 시행하였다. 계대 배양 2 일째 100 배율 광학 현 미경 하에서 전형적인 달걀 프라이 모양의 M. hominis집락이 


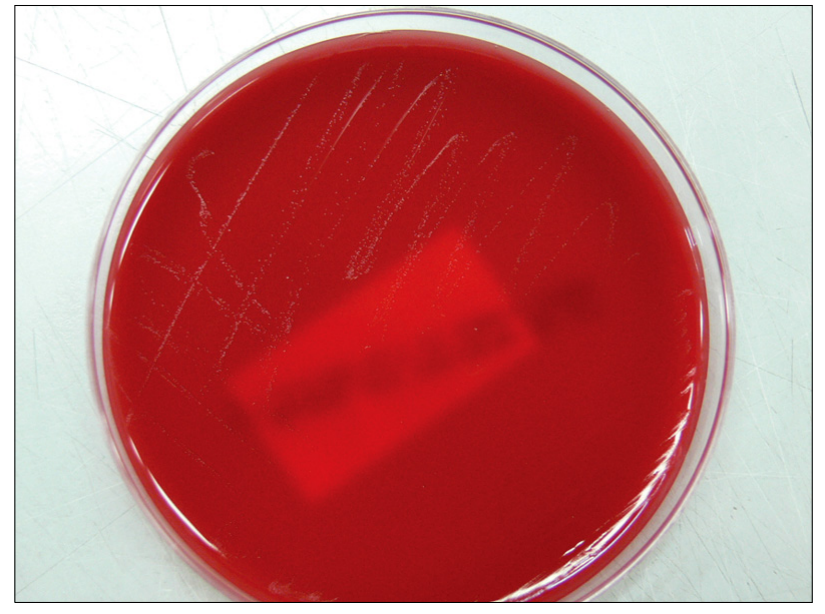

Fig. 1. Tiny, pinpoint colonies appeared after 4 days of incubation in Brucella agar.

관찰되었다(Fig. 2). 균의 정확한 동정을 위해 urogenital mycoplasma 특수배지인 urea-arginine LYO2 broth (BioMerieux, Marcy-l'Etoile, France)를 이용하여 동정 및 항생제 감수성 검 사를 시행하였다. 검사 결과 M. hominis로 동정되었고, doxycycline과 tetracycline에 감수성이나 ofloxacin, erythromycin, ciprofloxacin, azithromycin에 내성이었다. 또한 시발체 $16 \mathrm{~S}-4 \mathrm{~F}$ (5'-TTG GAG AGT TTG ATC CTG GCT-3'), 16S-534R (5'-TAC CGC GGC TGC TGG CAC-3')와 16S-27F (5'-AGA GTT TGA TCM TGG CTC AG-3'), 16S-801R (5'-GGC GTG GAC TTC CAG GGT ATC T-3')을 이용하여 16S rRNA 유전 자 절편을 증폭한 후 $743 \mathrm{bp}$ 의 염기서열을 얻었다. 이를 National Center For Biotechnology Information: The Basic Local Alignment Search Tool (NCBI BLAST)의 데이터베이스와 비교 하였을 때, M. hominis의 type strain인 GenBank accession number, M96660.1과 99.7\% 상동성을 가진 것으로 확인되었다. 환 자는 이후 기관지 내시경을 시행 받았고 기관지폐포 세척술을 통해 얻은 검체에서 Cytomegalovirus (CMV)-PCR 양성 결과를 보여 CMV로 인한 폐렴이 의심되어 foscarnet을 투여받았다. 또 한 급성 신부전 소견을 보여 급성 폐부종 진단하에 연속적 신 대치요법(continuous renal replacement therapy, CRRT)을 시행 받았다. 하지만 양측의 폐병변은 호전되지 않았고 환자는 $M$. hominis 동정 후 결과가 최종 보고되기 전에 사망하였다.

\section{2. 증례 2}

자궁내막암 진단 하에 복강경을 이용한 질식 자궁적출술 및 양측 자궁관난소절제술을 시행 받은 46세 여자 환자가 수술 후 7일째 39도에 이르는 발열과 수술 부위의 통증을 호소하였다. 혈액 검사상 백혈구 수 $17,530 / \mu \mathrm{L}$ (호중구 $82.8 \%$ ), 적혈구 침 강속도 $83 \mathrm{~mm} / \mathrm{hr}, \mathrm{C}$ 반응단백 $20.51 \mathrm{mg} / \mathrm{dL}$ 로 증가하였다. 환 자는 수술 후 예방적 항생제로 cefotetan을 투여 받는 중이었으

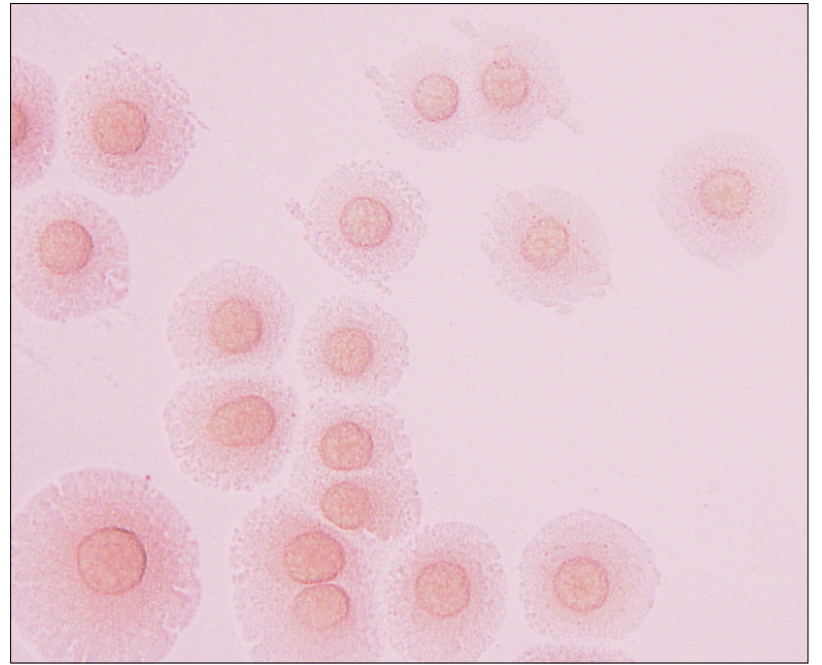

Fig. 2. Typical "fried-egg-type" colonies in PPLO agar under a light microscope $(\times 100)$. PPLO, pleuropneumonia-like organism.

며, 발열이 발생 후 혈액 배양검사 및 Jacson Pratt 카테터를 통 한 복수 배양검사가 의뢰되었다. 복수의 혐기성 배양 3 일째 부 루셀라 한천배지에서 핀 끝만한 크기의 작고 반투명한 집락이 관찰되었으나 그람 염색에서 균주는 관찰되지 않았다. Mycoplasma 감염 의심 하에 PPLO 배지에 계대 배양을 시행하였고 배양 2 일째 100 배율 광학 현미경하에서 M. hominis의 특징적 인 달걀프라이 모양의 집락을 관찰할 수 있었다. Urea-arginine LYO2 broth를 이용하여 M. hominis로 동정할 수 있었으며 함 께 시행한 항생제 감수성 검사에서 doxycycline, ofloxacin, ciprofloxacin에는 감수성이나 erythromycin, tetracycline에서는 내성을 보였다. 환자는 발열이 완전히 소실되지는 않았으나 임 상적으로 호전 양상을 보여 최종적인 균주의 분리 및 항생제 감수성결과가 보고되기 전이지만 수술 후 12 일째 퇴원하였다. 이후 결과 확인을 위해 퇴원 후 6 일째 외래 방문하였을 때 감 염 증상은 소실되었고 재발은 없었다.

\section{고 찰}

본 증례는 체액에서 분리된 M. hominis에 의한 비뇨생식기 외 감염에 대한 보고이다. 인공 슬관절 전치환술 후 관절액에 서 M. hominis가 분리된 2예가 국내에서 보고된 바 있으나[6], 흉수와 복수에서 M. hominis가 분리되었던 증례는 찾을 수 없 었다. M. hominis가 흉수에서 원인균으로 처음으로 보고되었던 증례는 1997년 Lyon 등[3]이 보고한 것으로 만성적인 폐색전증 으로 양측 폐이식술을 시행 받은 환자의 흉수와 폐조직에서 $M$. hominis가 분리되었다. Mufson 등[10]은 건강한 성인의 1 3\% 에서 호흡기 분비물 내 M. hominis가 분리되지만 만성적인 호 흡기 감염자에서는 $8 \%$, 급성 상기도 감염자에서는 $6 \%$ 로 동정 
률이 증가하여 M. hominis가 성인의 호흡기 감염과 연관이 있 음을 보고하였다. M. hominis가 복강내 감염 균주로 처음 보고 된 것은 1991년도 Diekman 등[11]이 보고한 것으로 지속성 외 래 복막투석을 받는 환자의 투석액으로부터 M. hominis가 분리 되었다. 이처럼 M. hominis가 비뇨생식기 외 감염을 일으킬 수 있는 이유는 아직까지 명확히 밝혀져 있지 않지만, 호흡기 감 염의 경우 상기도 분비물 내 상재해 있던 M. hominis의 미세한 흡인을 통한 것이라는 가설이 제시되고 있다[5]. 또한 요도 카 테터 삽입 등의 침습적인 술기 이후 비뇨생식기 계에 상재균인 M. hominis가 일시적인 균혈증을 일으키고 이를 체내의 면역 기능이 제거하지 못하는 경우, 수술 받았거나 사고에 의해 손 상 받은 부위로 균이 침입하여 비뇨생식기 외 감염을 일으키는 것으로 설명하고 있다[4].

M. hominis는 비교적 낮은 병원성을 보이는 균주이지만 경험 적으로 사용되는 항생제에 감수성을 보이지 않기 때문에 신속 한 균동정과 항생제 감수성 검사가 필요하다. 첫 번째 증례의 경우 사망에 이른 원인이 M. hominis에 의한 호흡기 감염만으 로 보기는 어려우며 신부전, 조혈모세포 이식에 따른 사망률 증가, 면역 저하에 따른 바이러스의 동반 감염 등이 함께 연관 되었을 것으로 생각해 볼 수 있다. 그러나 폐감염으로 인한 호 흡부전은 환자의 치료경과 악화에 매우 중요한 요인으로 분리 된 M. hominis 감염에 대한 적절한 항생제 치료가 조기에 수반 되었다면 치료 경과에 상당한 도움을 줄 수 있었을 것으로 생 각한다. 두 번째 증례의 경우 카테터를 통해 채취한 검체에서 M. hominis가 분리되었고 결과가 보고되기 전 임상증상이 호전 양상을 보여 퇴원한 점을 고려할 때 M. hominis에 의한 감염인 지 단순한 집락 형성인지에 대한 감별이 어렵다. 그러나 Pile[12]의 연구에 의하면 발열증상이 감염에 특이적인 지표는 아니지만 수술 후 5 일 이후에 발생한 경우 발열이 발생한 환자 의 약 $90 \%$ 에서 실제 감염이 있는 것으로 밝히고 있다. 환자의 경우 수술 후 7일째 발열이 발생하였으며 혈액검사상 백혈구 증가 및 적혈구 침강속도와 $\mathrm{C}$ 반응단백의 증가 등의 감염 증상 을 보였다. 환자의 임상 경과는 호전 양상을 보여 M. hominis감 염에 대한 치료 없이 퇴원이 가능하였으나 감염 증상으로 인해 총 재원기간이 7 일에서 12 일로 연장되었다.

M. hominis는 배양 조건이 까다롭고 3 5일 이상의 배양기 간이 필요하여 검사실에서 균분리가 쉽지 않다. 또한 세포벽이 없는 특성으로 그람 염색이 되지 않아 균의 존재를 쉽게 간과 할 수 있다. 따라서 M. hominis에 의한 감염을 의심하지 않은 상태에서는 균의 동정이 쉽지 않기 때문에 발생률의 보고는 실 제보다 더 낮을 수 있다. 본 증례에서 사용한 urogenital mycoplasma 특수배지인 urea-arginine LYO2 broth는 M. hominis가 arginine을 가수분해하는 대사반응을 이용한 액체배양법이다. 이는 24 48시간 배양 후 결과 판독이 가능하며 비교적 간편하 고 쉽게 균을 분리하고 동시에 항생제 감수성 검사를 시행할
수 있는 장점이 있다. Mycoplasma IST 2 (BioMerieux, Marcy-l'Etoile, France)와 MYCOFAST Evolution 2 (International micro-bio., France)가 액체배양법으로 널리 사용되고 있는 데 Park 등[13]의 연구에 의하면 A7 agar culture법에 대한 MYCOFAST법의 민감도와 특이도가 각각 $95 \%$ 와 $98 \%$ 로 비교 적 높이 나타나 신뢰할 만하며 항생제 감수성 검사까지 병행할 수 있어 유용한 진단법으로 보고하였다. 이밖에 중합효소연쇄 반응은 배양하기 어려운 균에 의한 감염질환의 진단에 유용하 게 쓰일 수 있는 방법으로 민감도와 특이도가 높고 비교적 신 속한 균 동정이 가능하지만 방법 자체가 매우 복잡하고 검사 장비가 비싸 대부분의 검사실에서 적용하기 어려운 단점이 있 다[13].

M. hominis는 특히 면역저하 환자에게서 폐렴, 복막염, 심내 막염 등의 전신적인 감염을 일으키는 균주로 지속적인 감염 증 상에도 불구하고 균주의 동정이 쉽지 않거나 경험적인 항생제 에 잘 반응하지 않을 경우, M. hominis에 의한 감염 가능성을 충분히 고려해야 한다. 이의 분리를 위해 통상적인 배양법과 함께 urea-arginine LYO2 broth이나 중합효소연쇄반응을 상호 보완적으로 시행함으로써 균을 좀 더 신속하게 분리할 수 있을 것으로 기대되며 이를 통해 조기에 적절한 치료를 할 수 있다 면 환자의 치료경과에 상당한 도움을 줄 수 있을 것으로 생각 하였다.

\section{참 고 문 헌}

1. Duffy LB, Crabb D, Searcey K, Kempf MC. Comparative potency of gemifloxacin, new quinolones, macrolides, tetracycline and clindamycin against Mycoplasma spp. J Antimicrob Chemother 2000;45(Suppl 1):29-33.

2. Yamaguchi M, Kikuchi A, Ohkusu K, Akashi M, Sasahara J, Takakuwa K, et al. Abscess formation due to Mycoplasma hominis infection after cesarean section. J Obstet Gynaecol Res 2009; 35:593-6.

3. Lyon GM, Alspaugh JA, Meredith FT, Harrell LJ, Tapson V, Davis $\mathrm{RD}$, et al. Mycoplasma hominis pneumonia complicating bilateral lung transplantation: case report and review of the literature. Chest 1997;112:1428-32.

4. Miranda C, Camacho E, Reina G, Turiño J, Rodríguez-Granger J, Yeste R, et al. Isolation of Mycoplasma hominis from extragenital cultures. Eur J Clin Microbiol Infect Dis 2005;24:334-7.

5. García C, Ugalde E, Monteagudo I, Saez A, Agüero J, Martinez-Martinez L, et al. Isolation of Mycoplasma hominis in critically ill patients with pulmonary infections: clinical and microbiological analysis in an intensive care unit. Intensive Care Med 2007;33:143-7.

6. Lee JH, Lee JH, Lee NY, Ha CW, Chung DR, Peck KR. Two cases of septic arthritis by Mycoplasma hominis after total knee replacement arthroplasty. Korean J Lab Med 2009;29:135-9.

7. Rohner P, Schnyder I, Ninet B, Schrenzel J, Lew D, Ramla T, et al. Severe Mycoplasma hominis infections in two renal transplant patients. Eur J Clin Microbiol Infect Dis 2004;23:203-4.

8. Kane JR, Shenep JL, Krance RA, Hurwitz CA. Diffuse alveolar 
hemorrhage associated with Mycoplasma hominis respiratory tract infection in a bone marrow transplant recipient. Chest 1994;105: 1891-2.

9. Camara B, Mouzin M, Ribes D, Esposito L, Guitard J, Game X, et al. Perihepatitis and perinephric abscess due to Mycoplasma hominis in a kidney transplant patient. Exp Clin Transplant 2007; 5:708-9.

10. Mufson MA. Mycoplasma hominis: a review of its role as a respiratory tract pathogen of humans. Sex Transm Dis 1983;10(4 Suppl):335-40.
11. Diekman MJ, Kuijper EJ, Boeschoten EW. Isolation of Mycoplasma hominis from peritoneal effluent of a CAPD patient. Perit Dial Int 1991;11:84-5.

12. Pile JC. Evaluating postoperative fever: a focused approach. Cleve Clin J Med 2006;73(Suppl 1):62-6.

13. Park HR, Kim YH, Lee HJ, Oh JS, Kim HJ. Usefulness of the mycofast test (MYCOFAST(R) Evolution 2) for the diagnosis of nongonococcal genitourinary infections. Korean J Urol 2006; 47:1117-23.

=국문초록=

\title{
Mycoplasma hominis에 의한 비뇨생식기 외 감염 2예
}

\author{
성균관대학교 의과대학 삼성서울병원 진단검사의학과 \\ 장미애, 송민정, 이장호, 이남용
}

Mycoplasma hominis는 비뇨생식기 계에 존재하는 공생균이다. M. hominis에 의한 비뇨생식기 외 감염은 면역 저하 환자 에게서 드물게 발생한다. 저자들은 M. hominis에 의한 비뇨생식기 외 감염 2예를 경험하였기에 보고하는 바이다. 첫 번째 증례의 환자는 혈관면역모세포 $\mathrm{T}$ 세포 림프종으로 진단 받은 여자 환자로 자가 말초혈액 조혈모세포 이식을 받았다. 두 번째 증례의 환자는 자궁내막암으로 복강경을 이용한 자궁 적출술을 받은 환자였다. 이후 두 환자는 발열을 포함한 감염 증상을 보였고 각각 흉수와 복수 배양검사에서 M. hominis가 분리되었다. 저자들은 정확하고 신속한 균주의 동정과 조기 치료가 환자의 치료경과에 상당한 도움을 줄 수 있음을 강조하고자 M. hominis에 의한 비뇨생식기 외 감염 2예를 문헌고 찰과 함께 보고하는 바이다. [대한임상미생물학회지 2010;13:47-50]

교신저자 : 이남용, $135-710$, 서울시 강남구 일원동 50번지

삼성서울병원 진단검사의학과

Tel: 02-3410-2706, Fax: 02-3410-2719

E-mail: micro.lee@samsung.com 